\title{
Molecular Characterization and Transcriptional Modulation of Stress-responsive Genes Under Heavy Metal Stress in Freshwater Ciliate, Euplotes Aediculatus
}

\section{Sripoorna Somasundaram}

University of Delhi Acharya Narendra Dev College

Jeeva Susan Abraham

University of Delhi Acharya Narendra Dev College

\section{Swati Maurya}

University of Delhi Acharya Narendra Dev College

Ravi Toteja

University of Delhi Acharya Narendra Dev College

\section{Renu Gupta}

Maitreyi College, University of Delhi

Seema Makhija ( $\square$ seemamakhija@andc.du.ac.in )

University of Delhi Acharya Narendra Dev College https://orcid.org/0000-0003-0615-8485

\section{Research Article}

Keywords: Cadmium, Catalase, Copper, Enzyme activity, Glutathione peroxidase, Heat-shock protein 70

Posted Date: May 27th, 2021

DOl: https://doi.org/10.21203/rs.3.rs-511435/v1

License: (c) (i) This work is licensed under a Creative Commons Attribution 4.0 International License.

Read Full License

Version of Record: A version of this preprint was published at Ecotoxicology on January 4th, 2022. See the published version at https://doi.org/10.1007/s10646-021-02518-y. 


\title{
Molecular characterization and transcriptional modulation of stress-responsive genes under heavy metal stress in freshwater ciliate, Euplotes aediculatus
}

Sripoorna Somasundaram ${ }^{1}$, Jeeva Susan Abraham ${ }^{1}$, Swati Maurya ${ }^{1}$, Ravi Toteja ${ }^{1}$, Renu Gupta ${ }^{2}$, and Seema Makhija ${ }^{1 *}$

${ }^{1}$ Ciliate Biology Laboratory, Acharya Narendra Dev College, University of Delhi, Delhi, India

${ }^{2}$ Zoology Department, Maitreyi College, University of Delhi, Delhi, India

*Corresponding author:

E-mail address: seemamakhija@andc.du.ac.in

\begin{abstract}
The concentration of heavy metals in the environment is increasing predominantly due to anthropogenic activities such as mining and other industrial activities. Exposure to metals above a certain threshold level induces deleterious effects in the living organisms. To survive such harsh environment, microbes possess a range of tolerance mechanisms and express stress-responsive genes and/or antioxidant enzymes to detoxify the metal stress. Protozoans, especially ciliates, are highly sensitive to the environmental changes, thereby making them suitable model systems for ecotoxicological studies. Thus, in the present work, the effect of heavy metals such as cadmium and copper has been studied in the freshwater ciliate, Euplotes aediculatus. This study focuses on the activity of antioxidant enzymes namely catalase and glutathione peroxidase in E. aediculatus under the heavy metal stress. Also, the expression of stress-responsive genes; heat-shock protein 70 ( $h s p 70$ ) and catalase (cat), has been studied after metal exposure. It was observed that the enzyme activity and the expression of these genes increased with an increase in the metal concentration and with the duration of metal exposure. Besides, these genes have been characterized to understand their role in cell defense. These genes of fresh water ciliate, therefore, can be used as molecular biomarkers to evaluate heavy metal toxicity.
\end{abstract}

Keywords: Cadmium; Catalase; Copper; Enzyme activity; Glutathione peroxidase; Heat-shock protein 70 


\section{Introduction}

Heavy metal contamination is increasing exponentially and rapidly in the environment especially in the aquatic ecosystems due to their high rate of solubility (Gheorghe et al. 2017; Hameed et al. 2020). Anthropogenic activities such as mining and industrial activities are the major source of heavy metal pollution (Gutiérrez et al. 2008; Jin et al. 2018; Malidareh et al. 2014; Nriagu and Pacyna 1988; Osman 2014; Peñuels and Filella 2002; Wong et al. 2016). Heavy metals are highly toxic and generate reactive oxygen species (ROS) that cause significant DNA or protein damage and lipid peroxidation which gradually induce cell death (Ali et al. 2019; Gutérrez et al. 2008; Leonard et al. 2004; Sharma et al. 2012; Valko et al. 2005). The living organisms especially the microbes express a range of tolerance mechanisms to combat metal stress (Gutiérrez et al. 2015; Igiri et al. 2018; Somasundaram et al. 2018). In the last few decades, the interest to study heavy metal interaction with the microorganisms has increased (Abraham et al. 2017; Arora et al. 1999; Jin et al. 2018; Kim et al. 2011; Makhija et al. 2015; Somasundaram et al. 2019; Toteja et al. 2017). Some of the mechanisms to combat heavy metal toxicity are activation of antioxidant enzymes and bioaccumulation of heavy metals by metal-binding proteins such as metallothionein (Abraham et al. 2017; Emamverdian et al. 2015; Ghori et al. 2019; Somasundaram et al. 2019; Toteja et al. 2017).

Ciliated protists are abundantly present in diverse habitats such as aquatic and terrestrial ecosystems (Abraham et al. 2019a). They play crucial role in shaping the microbial diversity in the aquatic ecosystems (Abraham et al. 2019a). Therefore, ciliate diversity and abundance are being linked in several studies to study the environmental changes (Abraham et al. 2019b; Jiang and Morin 2004; Maurya et al. 2020; Xu et al. 2014) and in monitoring the heavy metal pollution (Abraham et al. 2017; Gutiérrez et al. 2003; Somasundaram et al. 2018, 2019; Toteja et al. 2017; Vilas-Boas et al. 2020; Yeomans et al. 1997).

In this study, freshwater ciliate, Euplotes aediculatus collected from Sanjay Lake (Abraham et al. 2021) in Delhi, has been selected as model system to study the molecular defense mechanism exhibited by the ciliate under heavy metals (cadmium and copper) stress. $\mathrm{Cd}$ (non-essential heavy metal) and $\mathrm{Cu}$ (essential heavy metal) were selected for the present study since these two heavy metals have been previously reported to be highly toxic to the ciliate species (Abraham et al. 2017; Madoni 2010; Madoni and Romeo 2006; Martín-González et al. 2006; Pudpong and Chantangsi 2015). In the earlier studies, bioaccumulation, detoxification, and active involvement of antioxidant enzymes have been reported as cell defense mechanisms in the genus Euplotes, i.e. E. mutabilis (Rehman et al. 2006, 2008, 2009) and E. crassus (Kim et al. 2011, 2014; Kim et al. 2017; Mori et al. 2003). Toteja et al. (2017) has reported that the superoxide dismutase activity is enhanced in E. aediculatus in the presence of $\mathrm{Cd}$ and $\mathrm{Cu}$ to combat the metal stress. In the present work, the activity of antioxidant enzymes (catalase and glutathione peroxidase) and expression of stress-responsive genes (heat-shock protein 70 and cat) were studied after exposing the cells to different concentrations of heavy metals. Also, for the first time, the stress-responsive genes ( $h s p 70$ and cat) were characterized with respect to their structure and functions in Indian population of E. aediculatus and compared with the other closely related ciliate species to determine their role in molecular cell defense. 


\section{Material and methods}

\section{Water sample collection}

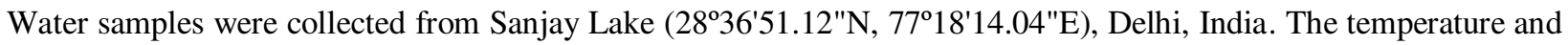
$\mathrm{pH}$ of the freshwater at the time of collection were $23^{\circ} \mathrm{C}$ and 7.2, respectively. Sanjay Lake is an artificial lake developed by the Delhi Development Authority (DDA). Its surface area is about $0.17 \mathrm{~km}^{2}$, depth of $1 \mathrm{~m}$ to $2.5 \mathrm{~m}$ and it has extensive growth of water hyacinth.

\section{In vitro culturing and identification of ciliates}

Several liters of water samples were strained through a mesh of size $<200 \mu \mathrm{m}$ and the concentrate containing ciliate fauna was transferred to large troughs in the laboratory. Mixed planktonic cultures were initially grown at room temperature with the addition of freshly boiled cabbage pieces to promote the growth of bacteria that serve as the food organism for the ciliates. Such water samples were subjected to periodic microscopic examination for about 510 days. Single cells were then isolated to raise clonal cultures. The clonal cultures were then grown in Pringsheim's medium (Chapman-Andresen 1958) and the temperature was maintained at $22-23^{\circ} \mathrm{C}$ (Abraham et al. 2021).

Identification of freshwater ciliates was done under a stereoscopic microscope, phase-contrast microscope and by molecular tools (Abraham et al. 2019a). Ciliary structures were identified by silver and protargol staining methods (Abraham et al. 2019a, 2021). Nuclear cytology was studied by Feulgen reaction (Chieco and Derenzini 1999; Feulgen and Rossenbeck 1924).

\section{Evaluation of heavy metal toxicity}

Toxicity assays for both heavy metals $(\mathrm{Cd}, \mathrm{Cu})$ were carried out to determine the tolerance degree limits (i.e. $0 \%$ to $100 \%$ survivability) of $E$. aediculatus (Sanjay Lake population). Stock solutions (1000 mg/L) of CdCl 2 and $\mathrm{CuSO}_{4}$ were prepared in Pringsheim's medium. $\mathrm{LC}_{30}, \mathrm{LC}_{50}$, and $\mathrm{LC}_{70}$ doses of $\mathrm{Cd}$ and $\mathrm{Cu}$ were determined in E. aediculatus by exposing 20 ciliate cells from the clonal cultures to a range of concentrations $-\mathrm{Cd}(1-10 \mathrm{mg} / \mathrm{L})$ and $\mathrm{Cu}(0.1-2.0$ $\mathrm{mg} / \mathrm{L}$ ), respectively. After $24 \mathrm{~h}$ of metal exposure, the ciliates were counted to determine their respective lethal dosages. Appropriate controls (without heavy metals) were also carried out (Abraham et al. 2017). The cells were accordingly exposed to varying concentrations (control, $\mathrm{LC}_{30}, \mathrm{LC}_{50}$, and $\mathrm{LC}_{70}$ ) of heavy metals $(\mathrm{Cd}$ and $\mathrm{Cu})$ and maintained at $22-23^{\circ} \mathrm{C}$ for $24 \mathrm{~h}$ to study the enzyme activities. For determining the gene expressions, along with control, the cells were exposed to $\mathrm{LC}_{50}$ doses of $\mathrm{Cd}$ and $\mathrm{Cu}$ for $24 \mathrm{~h}$ and $48 \mathrm{~h}$. All experiments were done in triplicates.

\section{Enzyme assays}

The activities of catalase (CAT) and glutathione peroxidase (GPx) enzymes were studied in Indian population of $E$. aediculatus under heavy metal stress. CAT activity was assayed by the method of Luck, 1963 and GPx by using Fortress kit. Control and treated cells (100 cells $/ \mathrm{ml})$ were pelleted separately. The pelleted cells were lysed in precooled mortar and pestle. Lysates were transferred to pre-cooled eppendorfs and were cold-centrifuged $\left(4^{\circ} \mathrm{C}\right)$ at 
10,000 rpm for $20 \mathrm{~min}$. The supernatants (enzyme extracts) were used to measure enzyme activities (Toteja et al. 2017). All the experiments were conducted in triplicates.

CAT enzyme assays

To $1 \mathrm{ml}$ of $10 \mathrm{mM} \mathrm{H}_{2} \mathrm{O}_{2}$ solution, $100 \mu \mathrm{l}$ of enzyme extract was added to study the activity. This was measured at $240 \mathrm{~nm}$ in a spectrophotometer (Genesys UV-VIS spectrophotometer) and the time required for decrease in absorbance was recorded at an interval of every $30 \mathrm{~s}$ for $2 \mathrm{~min}$. CAT activity is calculated in International unit where one unit is the amount of CAT enzyme necessary to decompose one $\mu$ moles of $\mathrm{H}_{2} \mathrm{O}_{2}$ per minute.

Catalase activity was calculated by:

\section{$\Delta A / \min \times$ volume of hydrogen peroxide \\ Molar coefficient of hydrogen peroxide $\times$ volume of enzyme extract}

GPx enzyme assays

$50 \mu \mathrm{l}$ of enzyme extract is mixed with the reaction reagents given in Fortress kit and absorbance was taken at 340 $\mathrm{nm}$ using UV-Vis spectrophotometer by taking readings at an interval of every $30 \mathrm{~s}$ for 2 min. GPx converts reduced glutathione (GSH) to oxidized glutathione (GSSG) in the presence of cumene hydroperoxide (provided by the kit). This is further catalysed by glutathione reductase and NADPH to produce reduced glutathione. During this reaction, NADPH is converted to NADP ${ }^{+}$. This decrease in absorbance of NADPH is measured at 340 nm using Genesys UVVis spectrophotometer.

The concentration of GPx was calculated by:

GPX concentration $(U / l)=8412 \times \Delta$ Absorbance $/ \mathrm{min}$

where,

$8412=\frac{\text { Total volume } \times 1000}{\text { Sample volume } \times \text { millimolar extinction coefficient } \times \text { light path }}$

\section{RNA isolation and cDNA preparation}

Total RNA was isolated from the control and heavy metals exposed cells of E. aediculatus (100 cells $/ \mathrm{ml}$ ) using Qiagen RNeasy Mini Kit (QIAGEN, India) and analyzed on 1.2\% formaldehyde agarose gel. cDNA was prepared from the isolated RNA by Qiagen Reverse Transcriptase kit (QIAGEN, India). Around 7-9 $\mu 1$ of RNA (350-500 ng of RNA) was used to prepare cDNA. 


\section{Real-time (quantitative) PCR (qRT-PCR)}

Primers of amplicon size 100-200 bp were designed for qRT-PCR using Primer3 online software and custom synthesized by M/s Biolinkk Pvt. Ltd. Primers of 103 bp amplicon size were designed from 18S rRNA gene (which was taken as an endogenous control for the reaction) of E. aediculatus (forward: 5'-TGT CAG AGG TGA AAT TCT CG-3', reverse: 5'-GTC TTT GAT CCC CTA ACT TTC-3') from GenBank accession number: KX867114 (Abraham et al., 2021); 177 bp amplicon size of hsp70 gene from Sanjay Lake (SL) population of E. aediculatus (forward: 5'- GCT GGA GTC ATT GCA GGA TT-3', reverse: 5'- CTG CAG TTG CCT TAA CTT CG-3'), and $121 \mathrm{bp}$ amplicon size of cat gene from SL population of E. aediculatus (forward: 5'-TAA CCA GGG AGC TTG GGA CT-3', reverse: 5'-GTG GGA TGA ATA TCC GTT C-3') were designed. To determine expression patterns of hsp70 and cat genes in control and heavy-metal treated cells $(\mathrm{Cd}$ and $\mathrm{Cu})$, quantitative real-time PCR was performed. Each PCR reaction included $1 \mu \mathrm{l}$ of cDNA and a $10 \mu \mathrm{M}$ primer set. Reaction conditions were as follows: $95^{\circ} \mathrm{C} / 3 \mathrm{~min} ; 40$ cycles of $95^{\circ} \mathrm{C} / 30 \mathrm{~s}, 60^{\circ} \mathrm{C} / 30 \mathrm{~s}$ with a $0.5^{\circ} \mathrm{C}$ increase for every $5 \mathrm{~s}$. qPCRs were performed using Applied Biosystems ViiA6. SYBR Green (Applied Biosystems, life technologies, Invitrogen) was used to detect specific amplified products. All experiments were done in triplicates. Data was collected as threshold cycle (CT) values and the fold change in the relative gene expression was calculated. To compare the expression levels of treated and control cells, the $2^{-\Delta \Delta C T}$ method was used. The change of threshold cycle number $(\Delta \mathrm{CT})$ was calculated as the difference between the CT values of the target genes and the reference genes for each sample. Similarly, $\Delta \Delta \mathrm{CT}$ value is calculated by subtracting the value of $\Delta \mathrm{CT}$ of treated cells with that of control (Somasundaram et al. 2019).

\section{Statistical analysis}

Results of enzyme assays were statistically analyzed using One Way ANOVA, Student's t-test (parametric tests) using XLSTAT software. Results of qPCRs were analyzed statistically where all the results were considered to be significant when $\mathrm{P}<0.05$ and values of fold change were mentioned as mean \pm standard deviation (SD).

\section{DNA extraction, amplification and sequencing}

The total genomic DNA from 50 cells $/ \mathrm{ml}$ culture of E. aediculauts (SL population) was extracted using Qiagen DNeasy blood \& tissue kit (QIAGEN, India) (Abraham et al. 2021). Primers for amplification of stress-responsive genes were designed by Primer3 online software and synthesized by M/s BioLinkk Pvt. Ltd. Primers used for cytosolic $h s p 70$ gene amplification in E. aediculatus were: forward primer 5'-TCA TGT GTC GGA GTA TGG GTT A-3' and reverse primer 5'-TGA TGA GTT GTT GGA CTT TTG G-3'. Additionally, two internal primers: one forward 5'-ATG CAG TCG TCA CAG TTC CA-3' and one reverse 5'-TTC TTC AAA TTT GCC CCT TG-3' were used. For amplification of cat gene in E. aediculatus, custom synthesized forward primer 5'-GAG TTG TTC ACG CCA AGG G-3' and revere primer 5'-GCA CCA AGT CTG TGT CTA TGG GT-3' were used. The PCR conditions were as follows: 1 st cycle at $95^{\circ} \mathrm{C}$ for $5 \mathrm{~min}, 50^{\circ} \mathrm{C}$ (for cytosolic $\left.h s p 70\right) / 56^{\circ} \mathrm{C}$ (for cat) for $1 \mathrm{~min}, 72^{\circ} \mathrm{C}$ for $1 \mathrm{~min}$ followed by 30 cycles with denaturation at $95^{\circ} \mathrm{C}$ for $45 \mathrm{~s}$, annealing at $50^{\circ} \mathrm{C} / 56^{\circ} \mathrm{C}$ for $45 \mathrm{~s}$ and extension at $72^{\circ} \mathrm{C}$ for $45 \mathrm{~s}$. And the last cycle with $95^{\circ} \mathrm{C}$ for $45 \mathrm{~s}, 50^{\circ} \mathrm{C} / 56^{\circ} \mathrm{C}$ for $45 \mathrm{~s}$ and $72^{\circ} \mathrm{C}$ for $10 \mathrm{~min}$. The PCR products of cytosolic 
hsp70 and cat genes obtained from the ciliates were run on $0.8 \%$ agarose gel and eluted by using Qiagen QIAquick gel extraction kit (QIAGEN, India). PCR amplified product of cytosolic $h s p 70$ and cat genes were sequenced by Sangers' di-deoxy method on Sequence Scanner Software 1.0 from Applied Biosystems, Inc. (AB1).

\section{Sequence analysis and molecular characterization of stress-responsive genes}

Basic Local Alignment Search Tool (BLAST) homology searches of databases were performed with the obtained nucleotide sequences from the NCBI (http://www.ncbi.nlm.nih.gov/blast). Amino acid sequences were deduced using ExPASy translate tool (http://web.expasy.org/translate/). Conserved domains were found using NCBI (National Center for Biotechnology Information) conserved domain search (CD-search; http://www.ncbi.nlm.nih.gov/Structure/cdd). The 3-D protein structures of $h s p 70$ and cat genes were predicted by Swiss-Model (http://swiss model .expasy.org/inter active) and I-TASSER online server (Yang and Zhang 2015). The structures were further analyzed to check the stereochemical quality from Ramachandran plot using Swiss-PDB viewer (Guex et al. 2009) and PROCHECK online software (Laskowski et al. 2001). The conserved domains in HSP70 and CAT protein were compared with the other ciliates and aligned using BioEdit 7.2.1 sequence alignment editor software (Hall 1999).

\section{In silico molecular docking studies of HSP70 and CAT proteins}

The predicted structures of the target proteins involved in cell defense mechanisms were used for molecular docking. Their respective substrates were retrieved from metal PDB (http://metalweb.cerm.unifi.it/) and/or PDB (Protein data bank) (https://www.rcsb.org/) which acted as ligands. The PDB files of target and its respective ligand were read as inputs for AutoDock4.2 software (http://autodock.scripps.edu/downloads/autodockregistration/autodock-4-2-download-page/) to carry out the docking simulation. Kollman united atom charges, solvation parameters and polar hydrogens were added to the target protein for docking simulation. AutoDock requires pre-calculated grid maps, one for each atom type, present in the ligand being docked as it stores the potential energy arising from the interaction with the target. This grid must surround the active site of the target protein. The Lamarckian Genetic Algorithm (LGA) was chosen to search for the best conformers. These were then further analyzed using Cygwin command (http://www.cygwin. com/install.html) to obtain around 10 conformations of target-ligand interaction files. These confirmations were finally visualized in Discovery Studio Visualizer (http://accelrys.com/products/discovery-studio/visualization-download.php) and the best conformation of targetligand file was selected from the 10 conformations with respect to their inhibition constant and binding energy and saved as the final image file (Rizvi et al. 2013). A comparative molecular docking was performed between $E$. aediculatus and other closely related species of the genus Euplotes to determine the difference in their active sites and functioning of the proteins. 


\section{Results}

\section{In vitro culturing and identification of ciliates}

Identifying features of Euplotes aediculatus (Sanjay Lake population)

Body size in vivo 107-119 x 72-82 $\mu \mathrm{m}$, size after protargol impregnation 81-107 x 52-74 $\mu \mathrm{m}$, length:width ratio approximately 1.5:1. Body shape rectangular, broadly obovate, and dorsoventrally flattened (Fig. 1). Adoral zone covers $69 \%$ of body length composed of 42-46 membranelles. Nine frontoventral cirri (six frontal and three ventral cirri), five transverse cirri, two left marginal cirri and two caudal cirri. Invariably eight dorsolateral kineties. Single macronucleus 3 -shaped and micronucleus about 2 or $3 \mu \mathrm{m}$ in diameter; distinctly separate from macronucleus, micronucleus located in a depression at the left anterior edge of macronucleus (Abraham et al. 2021). The macronuclear genome of E. aediculatus is similar to other spirotrich ciliates (Ammermann 1971; Jonsson and Lipps 2013). The macronuclear genome of $E$. aediculatus is formed from micronuclear genome by several reorganization steps (Ammermann 1971; Jonsson and Lipps 2013). The macronuclear genomes are arranged as tiny, gene-sized pieces with minimal amount of non-coding sequences (Ammermann 1971; Jonsson and Lipps 2013). Cytoplasm colourless, contains many refractive granules. Cells swim moderately fast, seen crawling on the substrate. Silverline system of double eurystomus (Abraham et al. 2021).

\section{Enzyme assays}

\section{CAT and GPx activity}

The activities of CAT and GPx enzymes were determined in E. aediculatus after exposing the cells to varying heavy metal concentrations, i.e. $0 \mathrm{mg} / \mathrm{L}$ (control), $1 \mathrm{mg} / \mathrm{L}\left(\mathrm{LC}_{30}\right), 2 \mathrm{mg} / \mathrm{L}\left(\mathrm{LC}_{50}\right)$ and $3 \mathrm{mg} / \mathrm{L}\left(\mathrm{LC}_{70}\right)$ of $\mathrm{Cd}$ and $0 \mathrm{mg} / \mathrm{L}$ (control), $0.1 \mathrm{mg} / \mathrm{L}\left(\mathrm{LC}_{30}\right), 0.2 \mathrm{mg} / \mathrm{L}\left(\mathrm{LC}_{50}\right)$, and $0.4 \mathrm{mg} / \mathrm{L}\left(\mathrm{LC}_{70}\right)$ of $\mathrm{Cu}$. The CAT activity increased in $E$. aediculatus with increase in heavy metal concentration but at higher doses of both $\mathrm{Cd}$ and $\mathrm{Cu}$, the activity of CAT enzyme decreased moderately but still significantly higher than that of control (Fig. 2a, Table 1). The GPx activity was dose dependent and increased significantly with increase in heavy metal concentration (Fig. 2b, Table1)

\section{Transcriptional modulation of stress-responsive genes after heavy metal exposure}

When the cells were exposed to heavy metals, significant increase in the expressions of the stress-responsive genes (cytosolic $h s p 70$ and cat) were noticed in E. aediculatus (Sanjay Lake population) when compared to the control/ unexposed cells. 
Cytosolic hsp70 gene

There was 3.25 fold increase in the expression of cytosolic $h s p 70$ gene after $24 \mathrm{~h}$ exposure and 2.13 fold increase in the expression after $48 \mathrm{~h}$ exposure to $\mathrm{LC}_{50}$ dose of $\mathrm{Cd}$. There was 1.85 fold increase and 2.48 fold increase in the expression of cytosolic $h s p 70$ gene after $24 \mathrm{~h}$ and $48 \mathrm{~h}$ exposure to $\mathrm{LC}_{50}$ dose of $\mathrm{Cu}$ (Fig. 3a).

cat gene

There was 1.75 fold increase in the expression of cat gene after $24 \mathrm{~h}$ exposure and 15.24 fold increase in the expression after $48 \mathrm{~h}$ exposure to $\mathrm{LC}_{50}$ dose of $\mathrm{Cd}$. There was 4.86 fold increase and 2.89 fold increase in the expression of cat gene after $24 \mathrm{~h}$ and $48 \mathrm{~h}$ exposure to $\mathrm{LC}_{50}$ dose of $\mathrm{Cu}$ (Fig. 3b).

\section{Characterization of stress-responsive genes}

\section{Cytosolic hsp70 gene}

The length of partially sequenced macronuclear cytosolic $h s p 70$ gene of $E$. aediculatus was $871 \mathrm{bp}$ and encoded a putative polypeptide of 290 aa (Fig. 4a) with putative molecular weight (MW) of $32.16 \mathrm{kDa}$ and pI of 5.64. The nucleotide sequence was submitted to GenBank database with the accession number MF804420. BLAST result of the nucleotide sequence showed $96.33 \%$ similarity with partially sequenced cytosolic hsp 70 gene of E. aediculatus (accession number AF031354), 92.16\% similarity with E. eurystomus (accession number L15291), 79.33\% similarity with completely sequenced cytosolic $h s p 70$ gene of E. nobilii (accession number DQ866998), and 76.78\% similarity with E. crassus (accession number AJ344550). BLAST result of predicted HSP70 protein sequence showed 96.90\% similarity with E. eurystomus (accession number AAA99875), 95.86\% with E. aediculatus (accession number AAC33419), 94.14\% with E. eurystomus (accession number AAA99874), 87.59\% with E. nobilii (accession number ABI23727), 83.79\% with E. focardii (accession number AAP51165), and 81.51\% with Euplotes crassus (accession number CAC69880). The predicted protein structure contains only an ATP binding domain having highly conserved domain (IFDLGGGTFDVSLL) specific for $h s p 70$ gene (Fig. 4b,c). Amino acid composition indicated that alanine content was predominantly present constituting $10 \%$ of the total protein and methionine and histidine were found to be relatively low (1\%). Ramachandran plot of this predicted model showed $94.7 \%$ in most favorable region showing that the model has good stereochemical quality.

\section{Catalase Gene (cat)}

The length of partially sequenced cat gene of E. aediculatus (SL Population) was 858 bp long coding for 286 aa. The partially sequenced cat gene was submitted to the GenBank database with the accession number MN044623. BLAST result of nucleotide sequences showed $81.64 \%$ similarity with E. vannus (accession number JN601111). BLAST result of predicted protein sequence of cat gene showed $81.47 \%$ similarity with E. vannus (accession number AEZ02310). The putative molecular weight and $\mathrm{pI}$ of the predicted CAT protein were $32.89 \mathrm{kDa}$ and 6.54 , respectively. Amino acid residue contained high content of aspartate and glycine and low content of cysteine. The 
amino acids that are involved in binding with heme group have been highlighted in Fig. 5a. The predicted homotetrameric structure of CAT protein contained heme group at the catalytic site of each monomer as shown in Fig. 5b-e. Ramachandran plot for this predicted model presented $96.04 \%$ of residues in the most favorable region showing that the model has a good stereochemical quality.

\section{Discussion}

For the present study, Sanjay Lake population of Euplotes aediculatus have been selected to study its defense mechanism to non-essential $(\mathrm{Cd})$ and essential $(\mathrm{Cu})$ heavy metals.

The activity of CAT enzyme was observed to be dose dependent in E. aediculatus though at higher doses $\left(\mathrm{LC}_{50} / \mathrm{LC}_{70}\right)$ of $\mathrm{Cd}$ and $\mathrm{Cu}$, there was a slight drop in the enzyme activity. Similar kind of result has been reported in Tetmemena sp. (freshwater ciliate species) where the activity of CAT increased with increase in heavy metal concentration but decrease in the enzyme activity has been reported at higher concentration (Somasundaram et al. 2019). In Euplotes vannus, the activity of CAT enzyme increased when treated with chemical, nitrofurazone (Hong et al. 2015). But with increase in chemical concentration and duration of exposure, the enzyme activity decreased (Hong et al. 2015). CAT activity was also observed to increase in Paramecium sp. in the presence of Cd (Benlaifa et al. 2016) and in green micro-algae (Scenedesmus sp. and Chlorella pyrenoidosa) under heavy metal (chromium, copper, lead, and zinc) stress (Ajayan and Selvaraju 2012). Similarly, under heavy metal ( $\mathrm{Cd}$ and $\mathrm{Cu}$ ) stress, increase in CAT activity was observed in brown mussels (Perna perna) (Boudjema et al. 2014) and in mangrove plant seedlings (Kandelia candel) where in the presence of $\mathrm{Cd}$, the activity of CAT enzyme increased with heavy metal concentration but started decreasing at higher metal concentration (Zhang et al. 2007).

In the present study, GPx activity was observed to increase steadily in E. aediculatus with increase in heavy metal concentration. Similar studies were conducted in plant, (Salvinia auriculata), in freshwater gammarid (Gammarus pulex), and in freshwater snail (Lymnaea natalensis) where the activity of this enzyme increased with increase in metal concentration (Mnkandla et al. 2019; Vestena et al. 2011). At very high concentrations of $\mathrm{Cd}$ and $\mathrm{Cu}$, the activity of GPx was also known to be inhibited but not as frequently as CAT enzyme (Somasundaram et al. 2019). GPx is most abundantly present in the cytoplasm of the living organisms and is relatively very less prone to the inhibitory effect of oxidative stress as compared to other antioxidant enzymes (Zitka et al. 2012; Zoidis et al. 2018). Since GPx belongs to selenoprotein family, it has selenium (Se) as cofactor, and this cofactor increases the stability of the enzyme and helps to fight effectively against oxidative stress effectively (Ferro et al. 2020; Zoidis et al. 2018). Se has an important role in fighting against the oxidative damage induced by heavy metals (Kumar et al. 2014; Malik et al. 2012). Since GPx has selenocysteine group in the active site, this enzyme, thus, appears to be a promising antioxidant enzyme in ROS detoxification.

Earlier studies have reported that heavy metal stress increases the activities of antioxidant enzymes in the living organisms immediately after exposure (Bhaduri and Fulekar 2012; Somasundaram et al. 2019; Toteja et al. 
2017). Since heavy metals induce the generation of reactive oxygen species (ROS), the activity of superoxide dismutase (SOD) increases to convert ROS to hydrogen peroxide (Toteja et al. 2017). This increases the activity of catalase to reduce the production of $\mathrm{H}_{2} \mathrm{O}_{2}$ (Somasundaram et al. 2019). But at higher concentration or prolonged exposure of heavy metals, the activity of antioxidant enzymes, i.e., SOD and CAT enzymes has been reported to decrease (Somasundaram et al. 2019; Toteja et al. 2017). At high concentrations of heavy metals, especially of redox inactive metals such as Cd, the activity of CAT enzyme is affected (Boudjema et al. 2014). Cd, at higher concentration, is known to induce toxic effect by binding to the sulfhydryl (-SH) group of heme (porphyrin ring) present at the active site of CAT enzyme, thereby lowering enzyme activity (Boudjema et al. 2014; Radhakrishnan 2008; Vestena et al. 2011).

However, GPx and GR are known to show decreased or low activity in the beginning of heavy metal exposure but gradually their activities are reported to increase with increase in metal concentration (Bhaduri and Fulekar 2012; Gomes-Junior et al. 2006). Heavy metals especially redox inactive metals such as Cd, decrease the concentration of GSH in the living organism for the synthesis of phytochelatin enzyme which acts as metal chelating enzyme (Bhaduri and Fulekar 2012; Gomes-Junior et al. 2006). With increase in heavy metal concentration, when CAT activity starts to decrease, GSH concentration increases gradually followed by GPx and GR activity to detoxify endogenous ROS such as hydrogen peroxide (Fang et al. 2019).

Results of qRT-PCR of cytosolic $h s p 70$ gene indicated that the expression of the gene increased in $E$. aediculatus with increase in heavy metal concentration. In the case of $\mathrm{Cd}$, there was a significant increase in the expression of cytosolic $h s p 70$ gene after $24 \mathrm{~h}$ ( $\mathrm{LC}_{50}$ dosage) and slight drop in the gene expression level after $48 \mathrm{~h}$ of metal exposure in E. aediculatus but still significantly higher than control. In $\mathrm{Cu}$ treated cells, the expression of stressresponsive genes increased significantly with increase in duration of metal exposure, i.e. after $24 \mathrm{~h}$ and $48 \mathrm{~h}$ of exposure (at $\mathrm{LC}_{50}$ dosage). Similar type of result was observed in Tambaqui fish (Colossoma macropomum) where expression of $h s p 70$ gene was highest after $3 \mathrm{~h}$ of $\mathrm{Cu}$ treatment whereas for Cd treatment, $h s p 70$ expression was upregulated after $1 \mathrm{~h}$ and lowered after $3 \mathrm{~h}$ (Casanova et al. 2013). Also, in Tetmemena sp., the transcriptional expression increased up to 46 fold after $24 \mathrm{~h}$ of Cd exposure ( $\mathrm{LC}_{50}$ dose) whereas it decreased to nine fold after $48 \mathrm{~h} \mathrm{Cd}$ exposure ( $\mathrm{LC}_{50}$ dose) (Somasundaram et al. 2019). However, in case of $\mathrm{Cu}$, the transcriptional expression of cytosolic hsp70 in Tetmemena sp. was observed to increase with increase in metal duration, i.e. around three fold increase after $24 \mathrm{~h}$ and 29 fold increase after $48 \mathrm{~h}$ of $\mathrm{Cu}$ exposure (Somasundaram et al. 2019). This supports that Cd leads to protein degradation at much faster rate as compared to $\mathrm{Cu}$ since $\mathrm{Cd}$ is non-essential heavy metal (Somasundaram et al. 2019). Also, $\mathrm{Cd}$ is known to inhibit many metalloproteins by binding and replacing essential ions resulting in protein damage (Tamás et al. 2014) and thereby upregulating $h s p 70$ gene at much faster rate as compared to $\mathrm{Cu}$.

The expression of cat gene increased in E. aediculatus when exposed to $\mathrm{LC}_{50}$ dose of $\mathrm{Cd}$ and $\mathrm{Cu}$ after $24 \mathrm{~h}$ but started to decrease after $48 \mathrm{~h}$ of metal exposure. Similar to this study, earlier reports have mentioned that the expression of cat gene increased in the presence of heavy metal stress in various organisms, but at higher concentrations of heavy metals, 
decrease in the gene expression has been observed (Aydin et al. 2016; Azpilicueta et al. 2008; Radhakrishnan 2008; Roh et al. 2006).

Heavy metals, at higher concentration, causes sudden increase in intracellular ROS levels which escape the scavenging activities of antioxidant enzymes and can significantly damage cell structure (Huang et al. 2019). These oxidative radicals, especially $\mathrm{H}_{2} \mathrm{O}_{2}$ and $\cdot \mathrm{OH}$ radical, can react with all biological molecules and induce DNA single-strand breakage, thus affecting the transcription of stress-responsive genes at higher concentration of metals (Hiramoto et al. 1996; Huang et al. 2019).

The alignment of HSP70 protein sequences of the different species of Euplotes (Fig. 6) showed that the highly conserved sequence of ATP binding domain (ABD), i.e., IFDLGGGTFDVSLLT, and cytosolic signature domain, i.e., VFDA, are identical in all the species. But difference was observed in the conserved sequence of NBD (N-binding domain) which is involved in dimerization, i.e., ADAAYNQVARNPTN. In E. aediculatus (present study), Ala (A) residue present in the beginning of the sequence, is different from the protein sequences of other species of genus Euplotes which have Gly $(\mathrm{G})$ residue. Also, Tyr ( $\mathrm{Y})$ in the conserved sequence was replaced with basic amino acids, i.e., Asn (N) in E. aediculatus, E. eurystomus and by Lys (K) in E. eurystomus, E. nobilii, E. focardii and E. crassus. Presence of basic amino acid such as Asn (N) helps in proper dimerization of HSP70 protein (Angelidis et al. 1999; Takakuwa et al. 2019).

The ATP binding domain of HSP70 protein was predicted in different species of genus Euplotes. It showed the presence of Arg, Lys and Glu residues bound to the ATP molecule in all Euplotes species (Fig. 7). This observation could be well supported with previously reported data where Arg and Glu have been observed to help in proper binding of ATP at the ATP binding site in HSP70 (Brehmer et al. 2001; Mayer and Gierasch 2019). Lysine at the catalytic site interacts with the phosphate group of ATP and helps in proper ATP hydrolysis (Brehmer et al. 2001; Mayer and Gierasch 2019). Lys and Glu residues are known to form salt bridge across the nucleotide-binding (ATP binding) cleft in both prokaryotes and eukaryotes (Brehmer et al. 2001; Mayer and Gierasch 2019). Arg present in $\mathrm{ABD}$ stabilizes the interaction of $\mathrm{ABD}$ with substrate binding domain (SBD) thereby helping in proper binding of substrate and enhancing HSP70 protein activity (Vogel et al. 2006). Since ATP binding domain of HSP70 is highly conserved, the predicted ATP binding site of HSP70 was similar in all the species of genus Euplotes.

The predicted protein sequence of CAT of E. aediculatus (present study) was compared with E. vannus. In general, CAT protein is reported to have Tyr $(\mathrm{Y})$ residue at the $\mathrm{C}$-terminal domain that acts as proximal heme ligand and His $(\mathrm{H})$ and Asn $(\mathrm{N})$ residues at the N-terminal domain (NTD) that act as catalytically active distal residues (Mashhadi et al. 2016; Zámocký and Koller 1999). But as observed in the present study, Lys (K) was observed instead of Asn (N) residue in E. aediculatus (Fig. 8).

The active sites of CAT protein were predicted and compared in both E. aediculatus and E. vannus. It has been reported that histidine binds to the porphyrin ring of heme at the catalytic site which is further stabilized by a cross-link with tyrosine residue (Mashhadi et al. 2016; Zámocký and Koller 1999). In the present study, presence of Asn was observed in E. vannus at the active site whereas in E. aediculatus, Lys was observed. Besides, serine and threonine residues were also observed in E. aediculatus near the active site (heme binding site) whereas these residues 
were absent at the active site of CAT protein in E. vannus (Fig. 9). It has been reported that Asn creates more polarity at the active site and hence enhances the enzyme function (Zámocký and Koller 1999). Presence of Ser and Thr at the catalytic site in SL population of E. aediculatus may help in maintaining the polarity at the active site, thus, sustaining the proper functioning of CAT protein.

\section{Conclusion}

In the present investigation, the activity of antioxidant enzymes (catalase and glutathione peroxidase), and expression of stress-responsive genes ( $h s p 70$ and cat) were studied under heavy metal $(\mathrm{Cd}$ and $\mathrm{Cu}$ ) stress for the first time in SL population of Euplotes aediculatus. The enzyme activity and the gene expression were observed to increase with increase in metal concentration indicating that these genes can be used as biomarkers to evaluate heavy metal toxicity. Also, the stress-responsive genes, i.e., hsp70 and cat, were characterized in Sanjay Lake population of E. aediculatus and compared with the other reported species of genus Euplotes. It was observed that since ATP binding domain of HSP70 protein is highly conserved, the ATP binding sites were similar in all the species. In CAT protein, change in the amino acid residue was observed in E. aediculatus where presence of His, Lys, Ser, and Thr were noticed at the catalytic site. Thus, in this study, the enzyme activity, transcriptional modulation and molecular characterization of stress-responsive genes show that these genes of $E$. aediculatus (SL population) can be used as indicators for assessing heavy metal toxicity.

\section{Data availability}

The nucleotide sequences obtained in this study have been deposited to GenBank, NCBI.

\section{Acknowledgements}

The authors appreciate the facilities provided by the Principal, Acharya Narendra Dev College, University of Delhi for carrying out the present study. The work was also supported by the Senior Research Fellowships to S Somasundaram from UGC (University Grants Commission) and JS Abraham and S Maurya from CSIR (Council of Scientific and Industrial Research), New Delhi, India.

\section{Authors' contributions}

R Toteja and S Makhija designed the present study. S Somasundaram, JS Abraham and S Maurya collected the freshwater samples and performed experiments. S Somasundaram and JS Abraham analyzed the data. S Somasundaram wrote the manuscript. S Makhija, R Toteja and R Gupta supervised this study and revised/ improved the manuscript. 


\section{Compliance with ethical standards}

\section{Conflicts of interest}

The authors declare no conflicts of interest.

\section{Consent to participate}

All authors consent to participate in this study.

\section{Consent for publication}

All authors consent for publication of this paper.

\section{References}

Abraham JS, Somasundaram S, Choudhary A, Toteja R, Gupta R, Makhija S, Warren A (2017) Assessment of heavy metal toxicity in four species of freshwater ciliates (Spirotrichea:Ciliophora) from Delhi, India. Curr Sci 113:21412150

Abraham J, Somasundaram S, Maurya S, Makhija S, Gupta R, Toteja R (2019a) Techniques and tools for species identification in ciliates: A review. Int J Syst Evol Microbiol 69. https://doi.org/10.1099/ijsem.0.003176

Abraham JS, Sripoorna S, Dagar J, Jangra S, Kumar A, Yadav K, Singh S, Goyal A, Maurya S, Gambhir G, Toteja R, Gupta R, Singh DK, El-Serehy HA, Al-Misned FA, Al-Farraj SA, Al-Rasheid KA, Maodaa SA, Makhija S (2019b) Soil ciliates of the Indian Delhi Region: Their community characteristics with emphasis on their ecological implications as sensitive bio-indicators for soil quality. Saudi J Biol Sci 26:1305-1313

Abraham JS, Somasundaram S, Maurya S, Gupta R, Makhija S, Toteja R (2021) Characterization of Euplotes lynni nov. spec., E. indica nov. spec. and description of E. aediculatus and E. woodruffi (Ciliophora, Euplotidae) using an integrative approach. Eur J Protistol 79:125779

Ajayan KV, Selvaraju M (2012) Heavy metal induced antioxidant defense system of green microalgae and its effective role in phycoremediation of tannery effluent. Pak J Biol Sci 15:1056-1062

Ali H, Khan E, Ilahi I (2019) Environmental chemistry and ecotoxicology of hazardous heavy metals: Environmental persistence, toxicity, and bioaccumulation. J Chem 2019:1-14

Ammermann D (1971) Morphology and development of the macronuclei of the ciliates Stylonychia mytilus and Euplotes aediculatus. Chromosoma 33:209-238 
Angelidis CE, Lazaridis I, Pagoulatos GN (1999) Aggregation of hsp70 and hsc70 in vivo is distinct and temperaturedependent and their chaperone function is directly related to non-aggregated forms. Eur J Biochem 259:505-512

Arora S, Gupta R, Machwe S, Sapra GR (1999) Influence of cadmium on development of surface ciliary structures in the ciliate Stylonychia mytilus (Ciliophora, Oxytrichidae). Europ J Protistol 35:281-289

Aydin S, Büyük İ, Gündüzer E, Büyük B, Kandemir I, Cansaran-Duman D, Aras S (2016) Effects of lead (Pb) and cadmium (Cd) elements on lipid peroxidation, catalase enzyme activity and catalase gene expression profile in tomato plants. Tarim Bilim Derg 22:539-547

Azpilicueta C, Pena L, Tomaro M, Gallego S (2008) Modifications in catalase activity and expression in developing sunflower seedlings under cadmium stress. Redox Rep: Commun Free Radic Res 13:40-46

Bhaduri AM, Fulekar MH (2012) Antioxidant enzyme responses of plants to heavy metal stress. Rev Environ Sci Biotechnol 11:55-69

Benlaifa M, Djebar MR, Berredjerm H, Benamara M, Ouali K, Djebar H (2016) Stress induced by cadmium: Its effects on growth respiratory metabolism, antioxidant enzymes and reactive oxygen species (ROS) of Paramecium sp. Int $\mathbf{J}$ Pharm Sci Rev Res 38:276-281

Boudjema K, Kourdali S, Bounakous N, Meknachi A, Badis A (2014) Catalase activity in Brown Mussels (Perna perna) under acute cadmium, lead, and copper exposure and depuration tests. J Mar Biol 2014:1-9

Brehmer D, Rüdiger S, Gässler CS, Klostermeier D, Packschies L, Reinstein J, Mayer MP, Bukau B (2001) Tuning of chaperone activity of Hsp70 proteins by modulation of nucleotide exchange. Nat Struct Biol 8:427-432

Casanova F, Honda R, Ferreira-Nozawa M, Aride P, Nozawa S (2013) Effects of copper and cadmium exposure on mRNA expression of catalase, glutamine synthetase, cytochrome P450 and heat shock protein 70 in Tambaqui Fish (Colossoma Macropomum). In: Gene expression to genetical genomics, Fish Biology Project, London, 6:1-8

Chapman-Andresen C (1958) Pinocytosis of inorganic salts by Amoeba proteus (Chaos diffluens). C R Trav Lab Carlsberg Chim 31:77-92

Chieco P, Derenzini M (1999) The Feulgen reaction 75 years on. Histochem Cell Biol 111:345-314

Emamverdian A, Ding Y, Mokhberdoran F, Xie Y (2015) Heavy metal stress and some mechanisms of plant defense response. Sci World J 2015:1-18

Fang W, Chi Z, Li W, Zhang X, Zhang Q (2019) Comparative study on the toxic mechanisms of medical nanosilver and silver ions on the antioxidant system of erythrocytes: From the aspects of antioxidant enzyme activities and molecular interaction mechanisms. J Nanobiotechnol 17:66 
Ferro D, Bakiu R, Pucciarelli S, Miceli C, Vallesi A, Irato P, Santovito G (2020) Molecular characterization, proteinprotein interaction network, and evolution of four glutathione peroxidases from Tetrahymena thermophila. Antioxidants 9:949

Feulgen R, Rossenbeck H (1924) Mikroskopisch-chemischerNachweis einer Nukleinšaure von Typus der Thymonukleins aureund die darauf beruhende selektive F־arbung von Zellkernenin mikroskopischen Praparaten. Hoppe-Seyler's Zeit. Physiol Chem 135:203-248

Gheorghe S, Stoica C, Vasile GG, Nita-Lazar M, Stanescu E, Lucaciu IE (2017) Metals toxic effects in aquatic ecosystems: Modulators of water quality. In: Water quality. IntechOpen, London, pp 59-89

Ghori NH, Ghori T, Hayat MQ, Imadi SR, Gul A, Altay V, Ozturk M (2019) Heavy metal stress and responses in plants. Int J Environ Sci Technol 16:1807-1828

Gomes-Junior R, Moldes C, Delite F, Pompeu G, Gratão P, Mazzafera P, Lea P, Azevedo R (2006) Antioxidant metabolism of coffee cell suspension cultures in response to cadmium. Chemosphere 65:1330-1337

Guex N, Peitsch MC, Schwede T (2009) Automated comparative protein structure modeling with Swiss-Model and Swiss-Pdb-Viewer: A historical perspective. Electrophoresis 30:S162-S173

Gutiérrez JC, Martín-González A, Díaz S, Ortega R (2003) Ciliate as potential source of cellular and molecular biomarker/biosensors for heavy metal pollution. Eur J Protistol 39:461-467

Gutiérrez JC, Martín-González A, Díaz S, Amaro F, Ortega R, Gallego A, de Lucas MP (2008) Ciliates as cellular tools to study the eukaryotic cell-heavy metal interactions. In: Brown SE, Welton WC (eds) Heavy metal pollution. Nova Science Publishers, New York, pp 1-44

Gutiérrez JC, Amaro F, Martín-González A (2015) Heavy metal whole-cell biosensors using eukaryotic microorganisms: an updated critical review. Front Microbiol 6:48

Hall TA (1999) Bioedit: a user-friendly biological sequence alignment editor and analysis program for windows 95/98/NT. Nucleic Acids Symp Ser 41:95-98

Hameed M, Dijoo ZK, Bhat RA, Qayoom I (2020) Concerns and threats of heavy metals' contamination on aquatic ecosystem. In: Bhat RA, Hakeem KR (eds) Bioremediation and biotechnology. Springer Nature, Switzerland, pp 1-18

Hiramoto K, Ojima N, Sako K, Kikugawa K (1996) Effect of plant phenolics on the formation of the spin-adduct of hydroxyl radical and the DNA strand breaking by hydroxyl radical. Biol Pharm Bull 19:558-563

Hong Y, Liu S, Lin X, Li J, Yi Z, Al-Rasheid KA (2015) Recognizing the importance of exposure-dose-response dynamics for ecotoxicity assessment: nitrofurazone-induced antioxidase activity and mRNA expression in model protozoan Euplotes vannus. Environ Sci Pollut Res Int 22:9544-9553 
Huang H, Ullah F, Zhou DX, Yi M, Zhao Y (2019) Mechanisms of ROS regulation of plant development and stress responses. Front Plant Sci 10:800

Igiri BE, Okoduwa SIR, Idoko GO, Akabuogu EP, Adeyi AO, Ejiogu IK (2018) Toxicity and bioremediation of heavy metals contaminated ecosystem from Tannery wastewater: A review. J Toxicol 2018:1-16

Jiang L, Morin PJ (2004) Temperature-dependent interactions explain unexpected responses to environmental warming in communities of competitors. J Anim Ecol 73:569-576

Jin Y, Luan Y, Ning Y, Wang L (2018) Effects and mechanisms of microbial remediation of heavy metals in soil: A critical review. Appl Sci 8:1336

Jonsson F, Lipps HJ (2013) The biology of telomeres in hypotrichous ciliates. In: Madame Curie bioscience database (internet), Landes Bioscence, Austin

Kim SH, Jung MY, Lee YM (2011) Effect of heavy metals on the antioxidant enzymes in the marine ciliate Euplotes crassus. Toxicol Environ Health Sci 3:213-219

Kim SH, Kim SJ, Lee JS, Lee YM (2014) Acute effects of heavy metals on the expression of glutathione-related antioxidant genes in the marine ciliate Euplotes crassus. Mar Pollut Bull 85:455-462

Kim SJ, Kim JH, Ju SJ (2017) Adaptation responses of individuals to environmental changes in the ciliate Euplotes crassus. Ocean Sci J 52:127-138

Kumar A, Singh RP, Singh PK, Awasthi S, Chakrabarty D, Trivedi PK, Tripathi RD (2014). Selenium ameliorates arsenic induced oxidative stress through modulation of antioxidant enzymes and thiols in rice (Oryza sativa L.). Ecotoxicology 23:1153-1163.

Laskowski RA, MacArthur MW, Thornton JM (2001) PROCHECK: Validation of protein structure coordinates. In: Rossmann MG, Arnold E (eds) International Tables of Crystallography, Volume F. Crystallography of Biological Macromolecules. Kluwer Academic Publishers, Netherlands, pp 722-725

Leonard SS, Bower JJ, Shi X (2004) Metal-induced toxicity, carcinogenesis, mechanisms and cellular responses. Mol Cell Biochem 255:3-10

Luck H (1963) Methods of Enzymatic Analysis. In: Bergmeyer HU (ed), $2^{\text {nd }}$ edn. Academic Press, Cambridge, pp 886.

Madoni P (2010) Protozoa in wastewater treatment processes: A minireview. Ital J Zool 78:3-11

Madoni P, Romeo M (2006) Acute toxicity of heavy metals towards freshwater ciliated protists. Environ Pollut $141: 1-7$ 
Makhija S, Gupta R, Toteja R, Abraham JS, Sripoorna S (2015) Cadmium induced ultrastructural changes in the ciliate, Stylonychia mytilus (Ciliophora, Hypotrichida). J Cell Tissue Res 15:5151-5157

Malidareh HB, Mahvi AH, Yunesian M, Alimohammadi M, Nazmara S (2014) Effect of fertilizer application on paddy soil heavy metals concentration and groundwater in North of Iran. Middle-East J Sci Res 20:1721-1727

Malik JA, Goel S, Kaur N, Sharma S, Singh I, Nayyar H (2012) Selenium antagonises the toxic effects of arsenic on mungbean (Phaseolus aureus Roxb.) plants by restricting its uptake and enhancing the antioxidative and detoxification mechanisms. Environ Exp Bot 77:242-248

Martín-González A, Díaz S, Borniquel S, Gallego A, Gutiérrez JC (2006) Cytotoxicity and bioaccumulation of heavy metals by ciliated protozoa isolated from urban wastewater treatment plants. Res Microbiol 157:108-118

Mashhadi Z, Newcomer ME, Brash AR (2016) The Thr-His connection on the distal heme of catalase-related hemoproteins: A hallmark of reaction with fatty acid hydroperoxides. ChemBioChem 17:2000-2006

Maurya S, Abraham JS, Somasundaram S, Toteja R, Gupta R, Makhija S (2020) Indicators for assessment of soil quality: A mini-review. Environ Monit Assess 192:604

Mayer MP, Gierasch LM (2019) Recent advances in the structural and mechanistic aspects of Hsp70 molecular chaperones. J Biol Chem 294:2085-2097

Mnkandla SM, Basopo N, Siwela AH (2019) The effect of persistent heavy metal exposure on some antioxidant enzyme activities and lipid peroxidation of the freshwater snail, Lymnaea natalensis. Bull Environ Contam Toxicol 103:551-558

Mori G, Erra F, Cionini K, Banchetti R (2003) Sublethal doses of heavy metals and Slow-Down pattern of Euplotes crassus (Ciliophora, Hypotrichia): A behavioural bioassay. Ital J Zool 70:23-30

Nriagu JO, Pacyna J (1988) Quantitative assessment of worldwide contamination of air water and soils by trace Metals. Nature 333:143-139

Osman KT (2014) Soil pollution. In: Soil degradation, conservation and remediation. Springer, Netherland, pp 149226

Peñuels J, Filella I (2002) Metal pollution in Spanish terrestrial ecosystems during the twentieth century. Chemosphere 46:501-505

Pudpong S, Chantangsi C (2015) Effects of four heavy metals on cell morphology and survival rate of the ciliate Bresslauides sp. Trop Nat Hist 15:117-125 
Radhakrishnan M (2008) Effect of cadmium on catalase activity in four tissues of freshwater fish Heteropneustes fossilis (Bloch.). Internet J Veterin Med 7:1-4

Rehman A, Shakoori R, Shakoori A (2006) Heavy metal resistant ciliate, Euplotes mutabilis, isolated from industrial effluents can decontaminate wastewater of heavy metals. Bull Environ Contam Toxicol 76:907-913

Rehman A, Shakoori FR, Shakoori AR (2008) Heavy metal resistant freshwater ciliate, Euplotes mutabilis, isolated from industrial effluents has potential to decontaminate wastewater of toxic metals. Bioresour Technol 99:3890-3895

Rehman A, Shakoori R, Shakoori A (2009) Heavy metal uptake by Euplotes mutabilis and its possible use in bioremediation of industrial wastewater. Bull Environ Contam Toxicol 83:130-135

Rizvi SMD, Shakil S, Haneef M (2013) A simple click by click protocol to perform docking: AutoDock 4.2 made easy for non-bioinformaticians. Excli J 12:831-857

Roh JY, Lee J, Choi J (2006) Assessment of stress-related gene expression in the heavy metal-exposed nematode Caenorhabditis elegans: A potential biomarker for metal-induced toxicity monitoring and environmental risk assessment. Environ Toxicol Chem 25:2946-2956.

Sharma P, Jha AB, Dubey RS, Pessarakli M (2012) Reactive oxygen species, oxidative damage, and antioxidative defense mechanism in plants under stressful conditions. J Bot 2012:1-26

Somasundaram S, Abraham JS, Maurya S, Makhija S, Gupta R, Toteja R (2018) Cellular and molecular basis of heavy metal-induced stress in ciliates. Curr Sci 114:1858-1865

Somasundaram S, Abraham JS, Maurya S, Toteja R, Gupta R, Makhija S (2019) Expression and molecular characterization of stress-responsive genes ( $h s p 70$ and $M n$-sod) and evaluation of antioxidant enzymes (CAT and GPx) in heavy metal exposed freshwater ciliate, Tetmemena sp. Mol Biol Rep 46:4921-4931

Takakuwa JE, Nitika, Knighton LE, Truman AW (2019) Oligomerization of hsp70: Current perspectives on regulation and function. Front Mol Biosci 6:1-81

Tamás MJ, Sharma SK, Ibstedt S, Jacobson T, Christen P (2014) Heavy metals and metalloids as a cause for protein misfolding and aggregation. Biomolecules 4:252-267.

Toteja R, Makhija S, Somasundaram S, Abraham JS, Gupta R (2017) Influence of copper and cadmium toxicity on antioxidant enzyme activity in freshwater ciliates. Indian J Exp Biol 55:694-701

Valko M, Morris H, Cronin MTD (2005) Metals, toxicity and oxidative stress. Curr Med Chem 12:1161-1208

Vestena S, Cambraia J, Ribeiro C, Oliveira JA, Oliva MA (2011) Cadmium-induced oxidative stress and antioxidative enzyme response in Water Hyacinth and Salvinia. Braz J Plant Physiol 23:131-139 
Vilas-Boas JA, Senra MVX, Dias RDP (2020) Ciliates in ecotoxicological studies: A minireview. Acta Limnol Bras 32:e202

Vogel M, Bukau B, Mayer MP (2006) Allosteric regulation of Hsp70 chaperones by a proline switch. Mol Cell 3:359367

Wong KW, Yap CK, Nulit R, Hamzah MS, Chen SK, Cheng WH, Karami A, Al-Shami SA (2016) Effects of anthropogenic activities on the heavy metal levels in the clams and sediments in a tropical river. Environ Sci Pollut Res 24:116-134

Xu H, Zhang W, Jiang Y (2014) Do early colonization patterns of periphytic ciliate fauna reveal environmental quality status in coastal waters? Environ Sci Pollut Res 21:7097-7112

Yang J, Zhang Y (2015) Protein structure and function prediction using I-TASSER. Curr Protoc Bioinform 52:5.8.15.8 .15

Zámocký M, Koller F (1999) Understanding the structure and function of catalases: Clues from molecular evolution and in vitro mutagenesis. Prog Biophys Mol Biol 72:19-66

Zhang FQ, Wang YS, Lou ZP, Dong J (2007) Effect of heavy metal stress on antioxidative enzymes and lipid peroxidation in leaves and roots of two mangrove plant seedlings (Kandelia candel and Bruguiera gymnorrhiza). Chemosphere 67:44-50

Zitka O, Skalickova S, Gumulec J, Masarik M, Adam V, Hubalek J, Trnkova L, Kruseova J, Eckschlager T, Kizek R (2012) Redox status expressed as GSH:GSSG ratio as a marker for oxidative stress in paediatric tumour patients. Oncol Lett 4:1247-1253

Zoidis E, Seremelis I, Kontopoulos N, Danezis GP (2018) Selenium-dependent antioxidant enzymes: Actions and properties of selenoproteins. Antioxidants (Basel) 7:66 


\section{Figure legends}

Fig. 1 Euplotes aediculatus. (a) From life; (b,c) Line diagrams showing (b) ventral and (c) dorsal surface; (d) after Feulgen staining; (e,f) after Protargol staining showing (e) ventral and (f) dorsal surface; (g,h) after silver staining showing (g) ventral and (h) dorsal surface. AZM: Adoral Zone of membranelles; CC: Caudal Cirri; DK: Dorsal Kineties; FC: Frontal Cirri; Ma: Macronucleus; MC: Marginal Cirri; Mi: Micronucleus; TC: Transverse Cirri; VC: Ventral Cirri. Scale bars: $50 \mu \mathrm{m}$

Fig. 2 Enzyme activity in Euplotes aediculatus; (a) Activity of catalase (CAT) and (b) activity of glutathione peroxidase $(\mathrm{GPx})$ under varying concentrations of $\mathrm{Cd}$ and $\mathrm{Cu}$. Data represent mean \pm S.D. of three replicates. Asterisks on the bar show the significance level [***: $\mathrm{P}<0.01$ (highly significant)]

Fig. 3 The relative mRNA expressions of stress-responsive ( $h s p 70$ and cat) genes in E. aediculatus at $\mathrm{LC}_{50}$ doses of Cd and $\mathrm{Cu}$ for $24 \mathrm{~h}$ and $48 \mathrm{~h}$ exposure; (a) $h s p 70$ gene expression, (b) cat gene expression. The level of gene expression was observed in relation to SSU rRNA (18S rRNA) gene which was used as a reference housekeeping gene. Data represent mean \pm SD of three replicates of exposed cell. Asterisks on the bar show the significance level $[* * *: \mathrm{P}<0.01$ (highly significant)]

Fig. 4 Cytosolic HSP70 of Euplotes aediculatus (SL population). (a) Nucleotide and protein sequence of cytosolic hsp70 gene where sequence in red represents conserved region, (b) Predicted protein structure of HSP70 protein by Swiss-model showing conserved region in ATP binding domain and (c) predicted 3D structure of ATP binding domain by Autodock software showing ATP binding site

Fig. 5 Catalase protein of Euplotes aediculatus; (a) Nucleotide and protein sequence of cat gene where the conserved catalytic site and heme-ligand signature motifs which are involved in binding to the heme group, (b,c) Predicted 3D structure of CAT protein predicted by Swiss-model showing (b) Homotetrameric and (c) monomeric units, (d,e) Protein structure showing heme group binding sites in CAT protein in a single monomer (arrow) predicted by (d) Autodock software and (e) I-TASSER online server

Fig. 6 Comparison of HSP70 protein sequences in Euplotes aediculatus (present study in bold) with other species of the genus Euplotes. The sequence inside the black box indicates the conserved sequences in the NBD (N-binding domain), blue box represents cytosolic signature domain, the red box indicates the universally conserved sequences and green box represents nuclear localization sequence of ATP Binding Domain (ABD)

Fig. 7 HSP70 protein of different species of the genus Euplotes showing ATP binding domain. (a) Euplotes aediculatus (present study), (b) Euplotes aediculatus, (c,d) Euplotes eurystomus, (e) Euplotes nobilii, (f) Euplotes focardii, and (g) Euplotes crassus

Fig. 8 Alignment of CAT protein of Euplotes aediculatus and Euplotes vannus. Boxes in the sequence represent conserved domains and circles indicate the catalytic sites 
Fig. 9 (a,c) Predicted 3D structure of CAT protein in Euplotes aediculatus (a) and Euplotes vannus (c) where the white circle represents the active site; (b,d) 3D representation of active site of CAT protein in E. aediculatus (b) and E. vannus (d) showing the crucial residues (marked in white boxes) involved in the catalytic reaction 
Figures
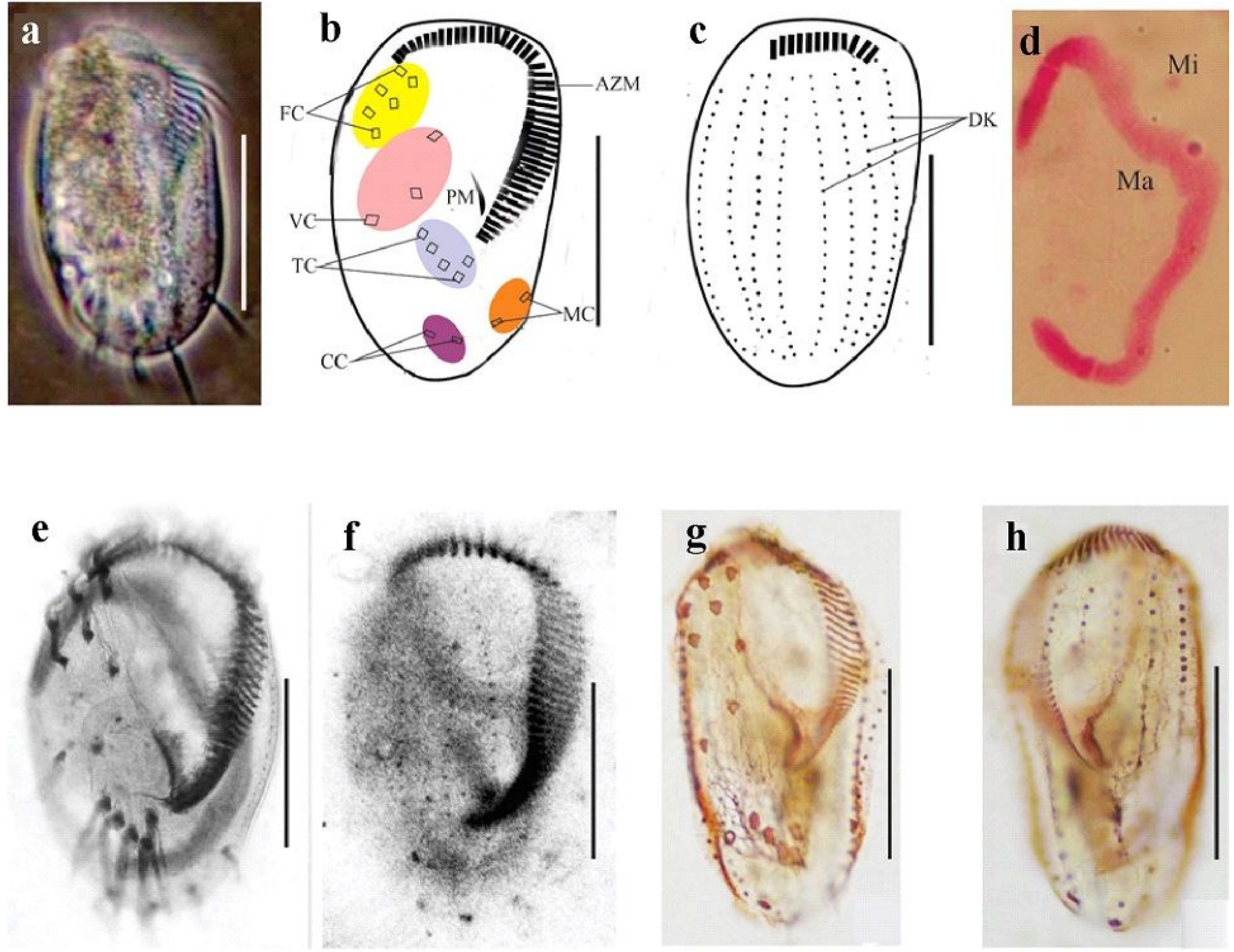

Figure 1

Euplotes aediculatus. (a) From life; (b,c) Line diagrams showing (b) ventral and (c) dorsal surface; (d) after Feulgen staining; (e,f) after Protargol staining showing (e) ventral and (f) dorsal surface; $(g, h)$ after silver staining showing $(\mathrm{g})$ ventral and $(\mathrm{h})$ dorsal surface. AZM: Adoral Zone of membranelles; CC: Caudal Cirri; DK: Dorsal Kineties; FC: Frontal Cirri; Ma: Macronucleus; MC: Marginal Cirri; Mi: Micronucleus; TC: Transverse Cirri; VC: Ventral Cirri. Scale bars: $50 \mu \mathrm{m}$ 

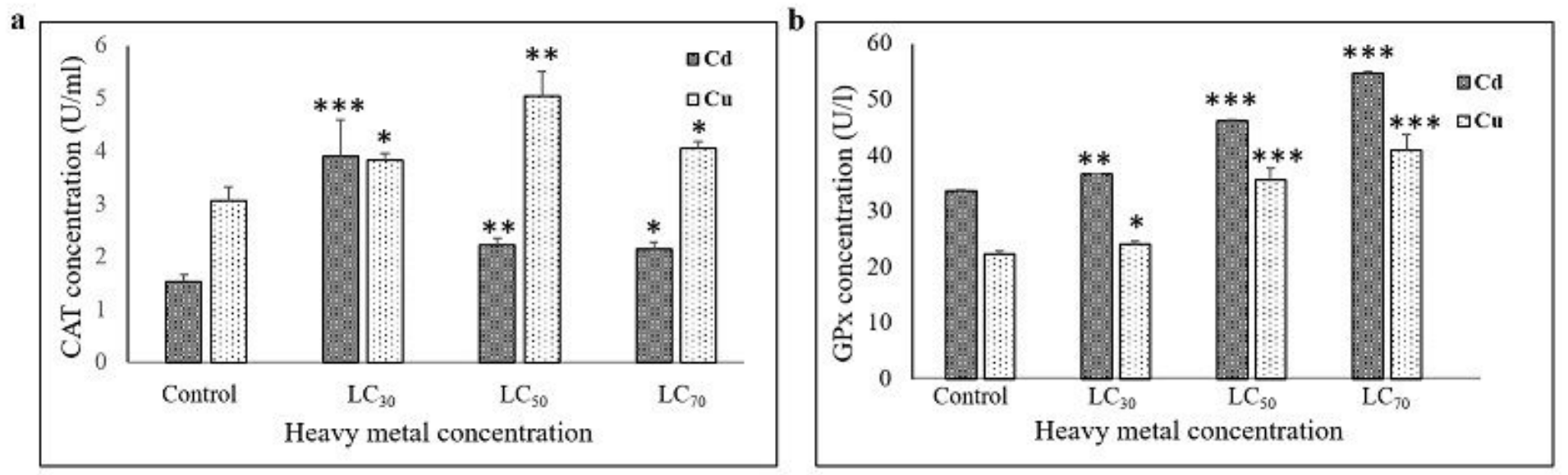

Figure 2

Enzyme activity in Euplotes aediculatus; (a) Activity of catalase (CAT) and (b) activity of glutathione peroxidase (GPx) under varying concentrations of $\mathrm{Cd}$ and $\mathrm{Cu}$. Data represent mean \pm S.D. of three replicates. Asterisks on the bar show the significance level [***: $P<0.01$ (highly significant)]
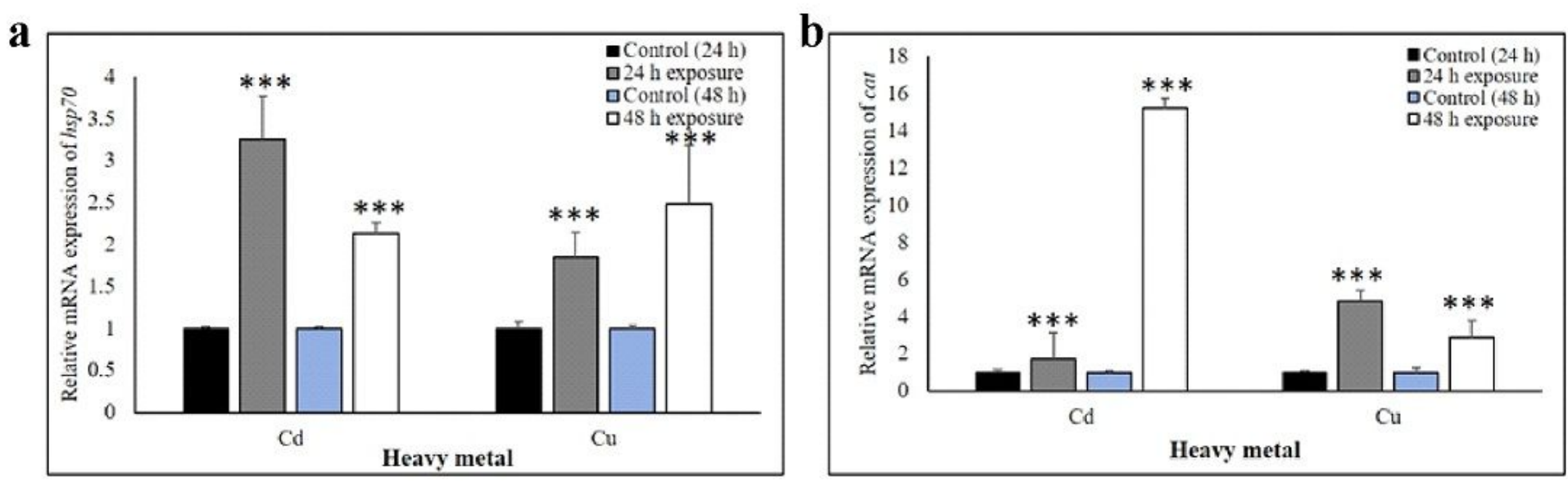

\section{Figure 3}

The relative mRNA expressions of stress-responsive (hsp70 and cat) genes in E. aediculatus at LC50 doses of $\mathrm{Cd}$ and $\mathrm{Cu}$ for $24 \mathrm{~h}$ and $48 \mathrm{~h}$ exposure; (a) hsp70 gene expression, (b) cat gene expression. The level of gene expression was observed in relation to SSU rRNA (18S rRNA) gene which was used as a reference housekeeping gene. Data represent mean \pm SD of three replicates of exposed cell. Asterisks on

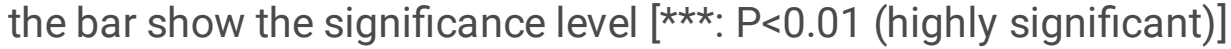




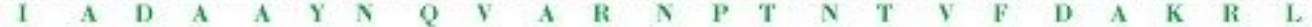
TAT TGG AAG AAA GTT CAA TGA TAC AGT TGT CCA AGA AGA TAT TAA ACT TTG GCC ATT CAA AGT TGA GAG

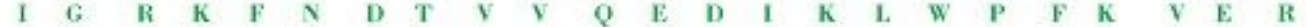
AGg AGC TGA TGA CAA ACC AAT GAT TAG AGT TGA TTT CAA GGg TGA ATC TAA GTT GTT CCA AGC TGA ACA

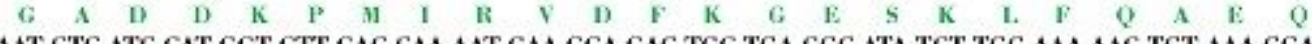
ATT CTC ATC CAT GGT CTT GAC CAA AAT GAA GGA GAC TGC TGA GGC ATA TCT TGG AAA AAC TGT AAA GGA

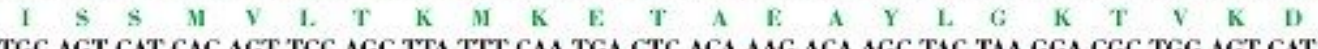
TGC AGT CAT CAC AGT TCC AGC TTA TTT CAA TGA CTC ACA AAG ACA AGC TAC TAA GGA CGC TGg AGT CAT

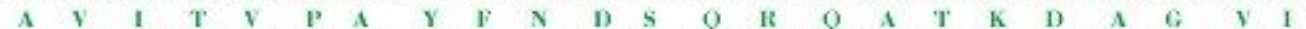
TGC AGg ATT GAA CGT TCT CAG AAT CAT CAA CGA GCC ANC TGC AGC AGC TAT TGC ATA CGg ACT TGA CAA $\begin{array}{lllllllllllllllllllllll}A & G & L & N & Y & L & \mathrm{I} & \mathrm{I} & \mathrm{I} & \mathrm{N} & \mathrm{E} & \mathrm{P} & \mathrm{T} & \mathrm{A} & \mathrm{A} & \mathrm{A} & \mathrm{I} & \mathrm{A} & \mathrm{Y} & \mathrm{G} & \mathrm{L} & \mathrm{D} & \mathrm{K}\end{array}$ AA ATC ATC AAC TGA GAA GAA TGT TCT CAT CTT CGA TCT TGG TGG TGG TAC ATT CGA TGT CTC ATT ACT $\begin{array}{lllllllllllllllllllllll}\mathrm{K} & \mathrm{S} & \mathrm{S} & \mathrm{T} & \mathrm{E} & \mathrm{K} & \mathrm{V} & \mathrm{V} & \mathrm{L} & \mathbf{I} & \mathrm{F} & \mathrm{D} & \mathrm{L} & \mathrm{G} & \mathrm{G} & \mathrm{G} & \mathrm{T} & \boldsymbol{F} & \mathrm{D} & \boldsymbol{V} & \mathrm{S} & \mathbf{L} & \mathbf{L}\end{array}$ AAC AAT TGA AGA AGG AAT CTT CGA AGT TAA GGC AAC TGC AGG AAA CAC TCA CTT AGG AGG AGA AGA CTT

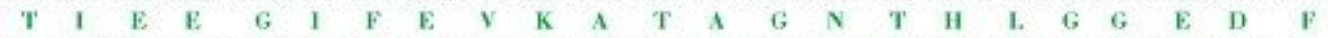
CGA TCA TAG ATT GGT TGA GTT CTG CCA AGC AGA TTT CAA GAA GAA GAC TAA GAT TGA TAT TTC TGA CAA

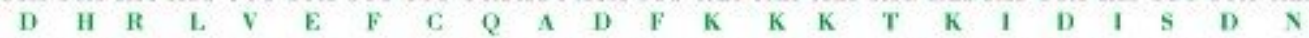
TCC AAG AGC TTT AAG AAG ACT TAG AAC TCA ATG CGA AAA AGC TAA AAG AAT TCT ATC AAC TGC AGT TAA $\begin{array}{lllllllllllllllllllllllll}P & R & A & L & R & R & L & R & T & O & C & E & K & A & K & R & \text { I } & \text { L } & S & T & A & y & N\end{array}$ CGC AAA CAT TGA GTG CGA AGC TTT AGC TGA AGg AGA AGA TTA CAG TGT TAG TCT CAC AAg AGC TAA ATI

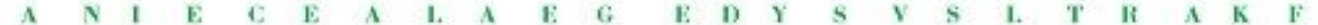
TGA AGA GCT CAA CAT TGA TTT GTT CAG AAA GTG TAT TCC ACC AGT CGA GAA AGT TCT AAA TGA TGC TGA

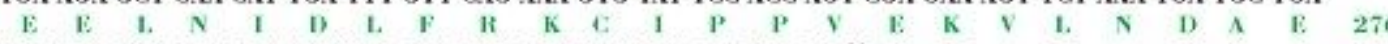
ACT TTC AAA AGA CCA AAT TCA CGA AGT CGT CTT AGT CGG AGG T -3'
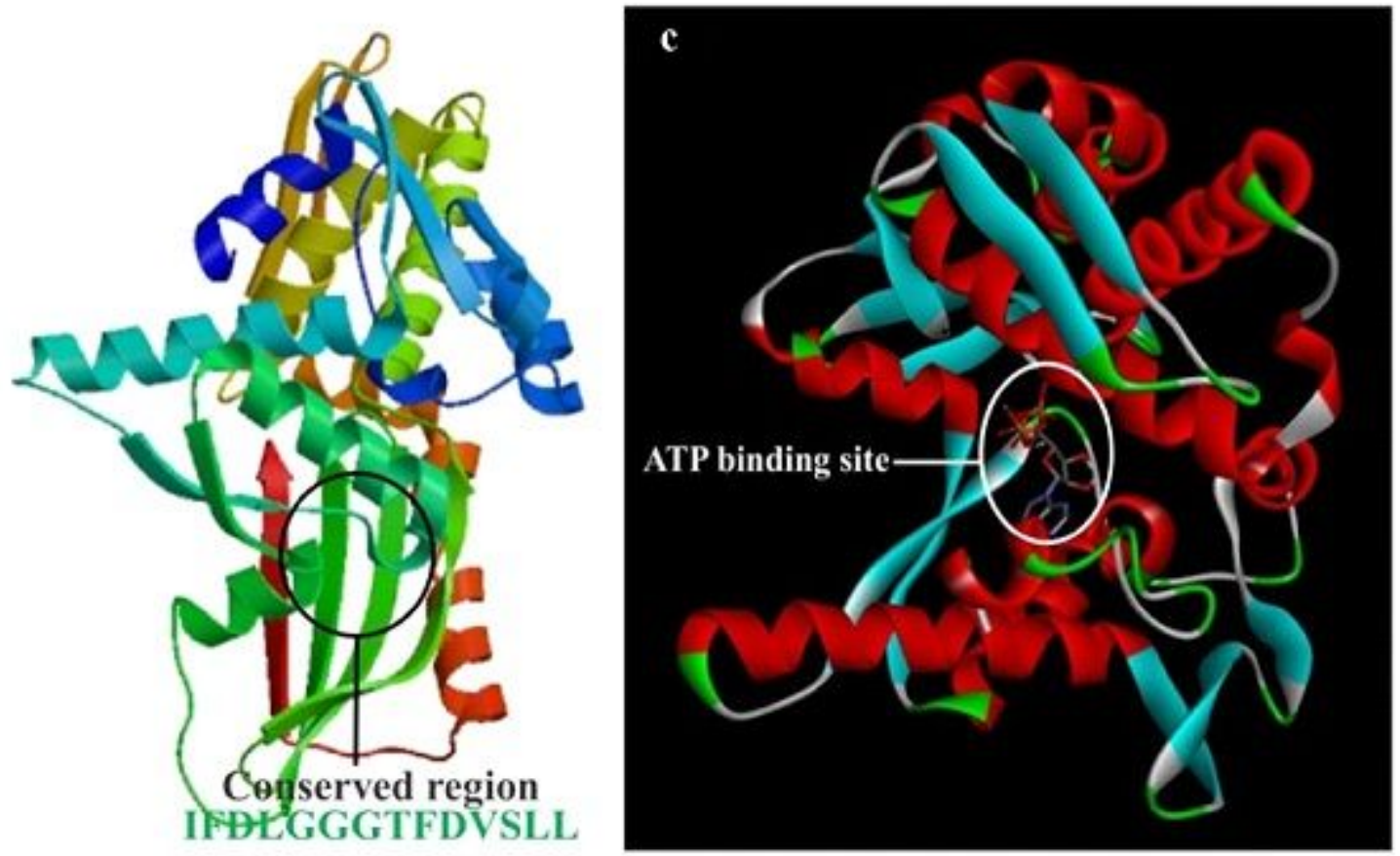

\section{Figure 4}

Cytosolic HSP70 of Euplotes aediculatus (SL population). (a) Nucleotide and protein sequence of cytosolic hsp70 gene where sequence in red represents conserved region, (b) Predicted protein structure of HSP70 protein by Swiss-model showing conserved region in ATP binding domain and (c) predicted 3D structure of ATP binding domain by Autodock software showing ATP binding site 


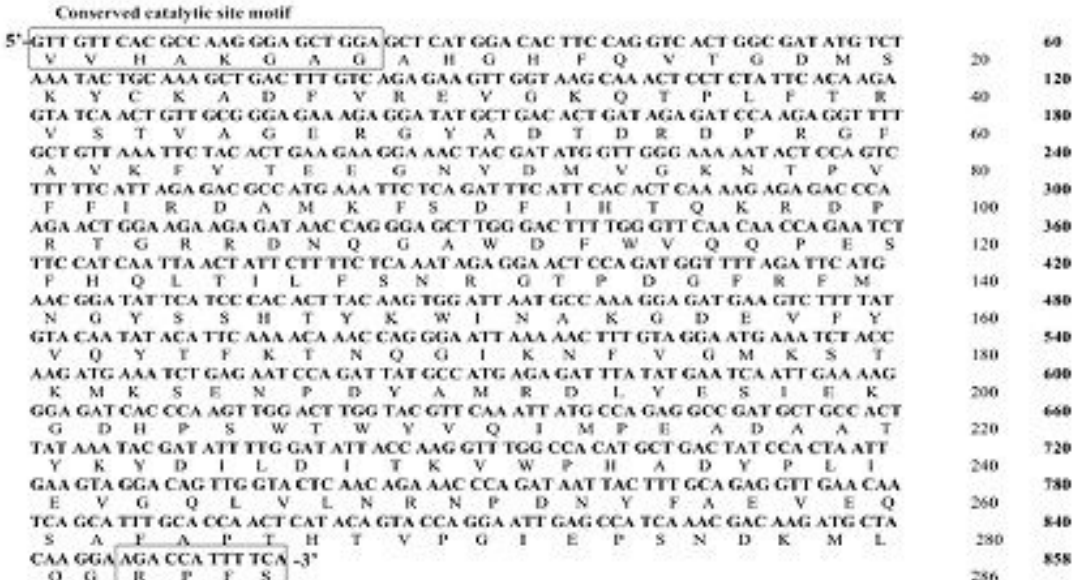

b

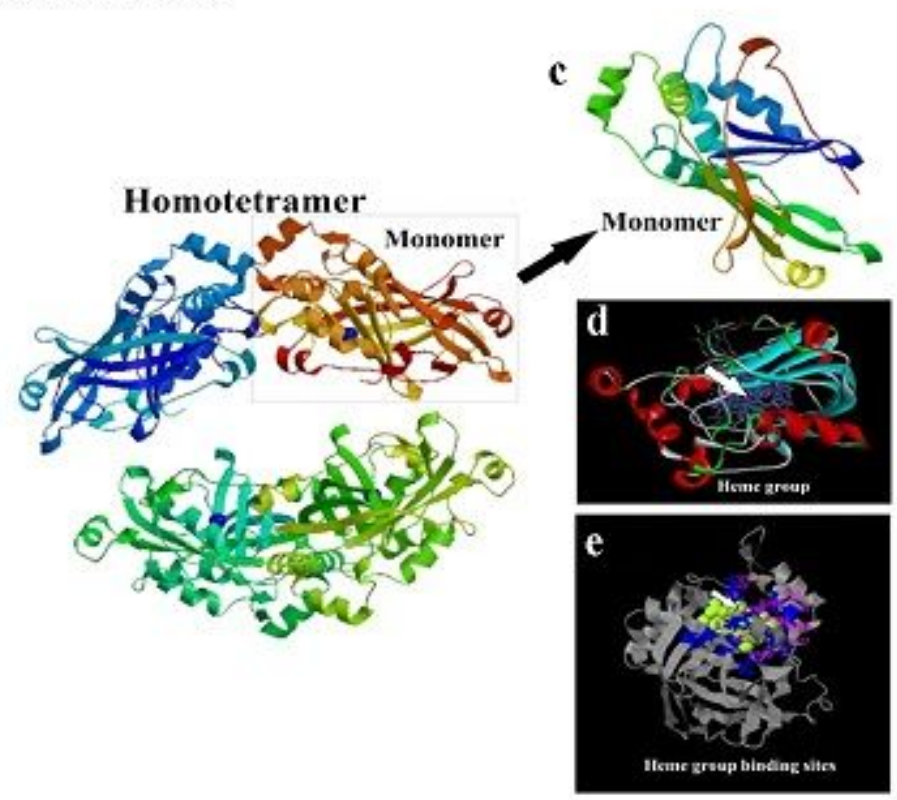

Figure 5

Catalase protein of Euplotes aediculatus; (a) Nucleotide and protein sequence of cat gene where the conserved catalytic site and heme-ligand signature motifs which are involved in binding to the heme group, $(b, c)$ Predicted 3D structure of CAT protein predicted by Swiss-model showing (b) Homotetrameric and (c) monomeric units, $(\mathrm{d}, \mathrm{e})$ Protein structure showing heme group binding sites in CAT protein in a single monomer (arrow) predicted by (d) Autodock software and (e) I-TASSER online server 


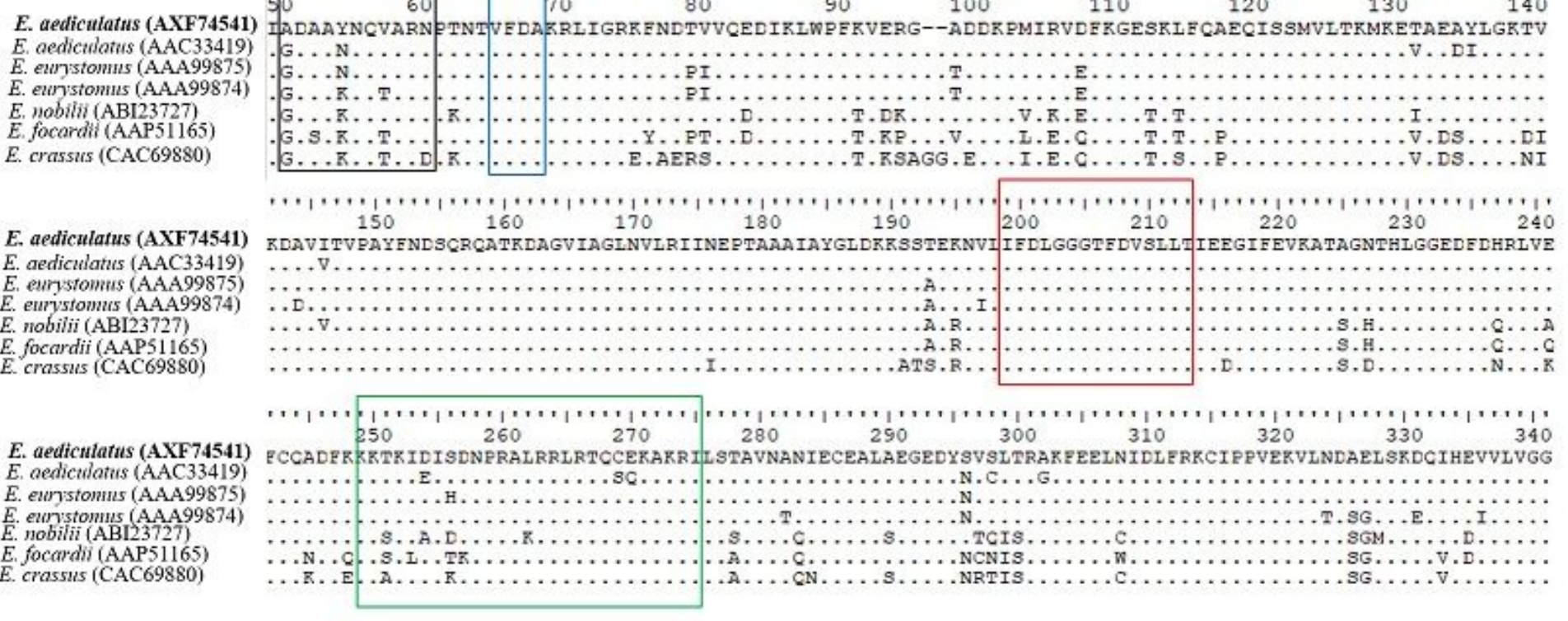

\section{Figure 6}

Comparison of HSP70 protein sequences in Euplotes aediculatus (present study in bold) with other species of the genus Euplotes. The sequence inside the black box indicates the conserved sequences in the NBD (N-binding domain), blue box represents cytosolic signature domain, the red box indicates the universally conserved sequences and green box represents nuclear localization sequence of ATP Binding Domain (ABD) 

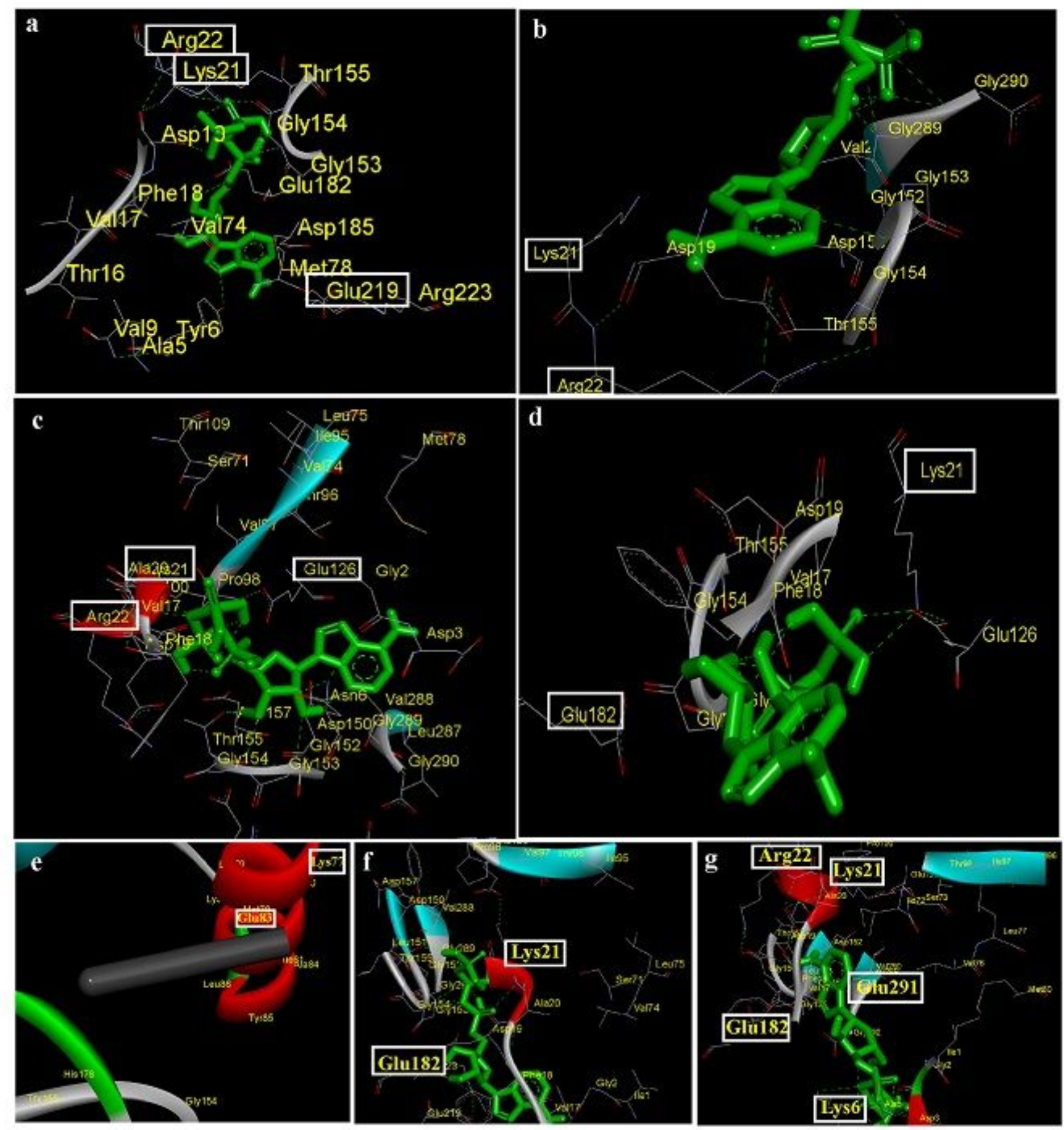

Figure 7

HSP70 protein of different species of the genus Euplotes showing ATP binding domain. (a) Euplotes aediculatus (present study), (b) Euplotes aediculatus, (c,d) Euplotes eurystomus, (e) Euplotes nobilii, (f) Euplotes focardii, and (g) Euplotes crassus 
E. aedicutatus (QDJ95747)

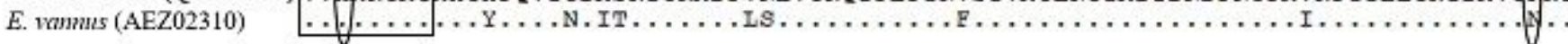

$\ldots, \ldots, \ldots, \ldots, \ldots, \ldots, \ldots, \ldots, \ldots, \ldots, \ldots, \ldots, \ldots, \ldots, \ldots, \ldots, \ldots, \ldots, \ldots, \ldots$

$$
\begin{array}{lllllll}
140 & 150 & 160 & 170 & 180 & 190 & 200
\end{array}
$$

E. aediculatus (QDJ95747) PVF IRDAMRF SDE IHTCKRDPRTGRRDNCGAWDFWVCCPESFHCLTILFSNRGTPDGFREMNGYSSHTYKW INARGDEV

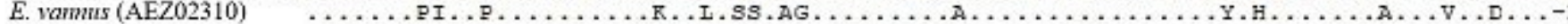

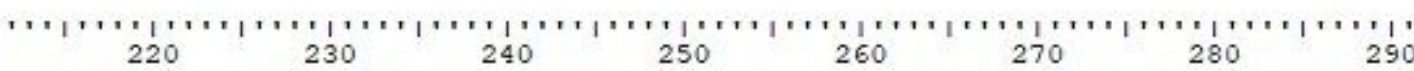

E. aedicuIatus (QDJ95747) FYVCYTEKTNCGIRNEVGMRSTRMRSENPDYAMRDLYESIERGDHPSWTWYVCIMPEADAATYRYDIIDITKVWPHADYP

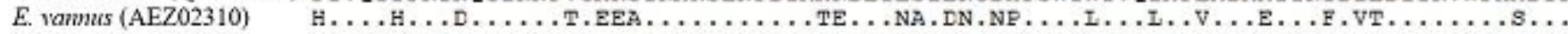

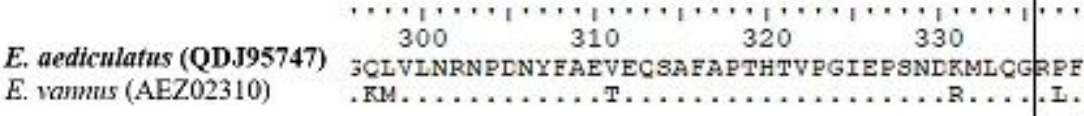

\section{Figure 8}

Alignment of CAT protein of Euplotes aediculatus and Euplotes vannus. Boxes in the sequence represent conserved domains and circles indicate the catalytic sites

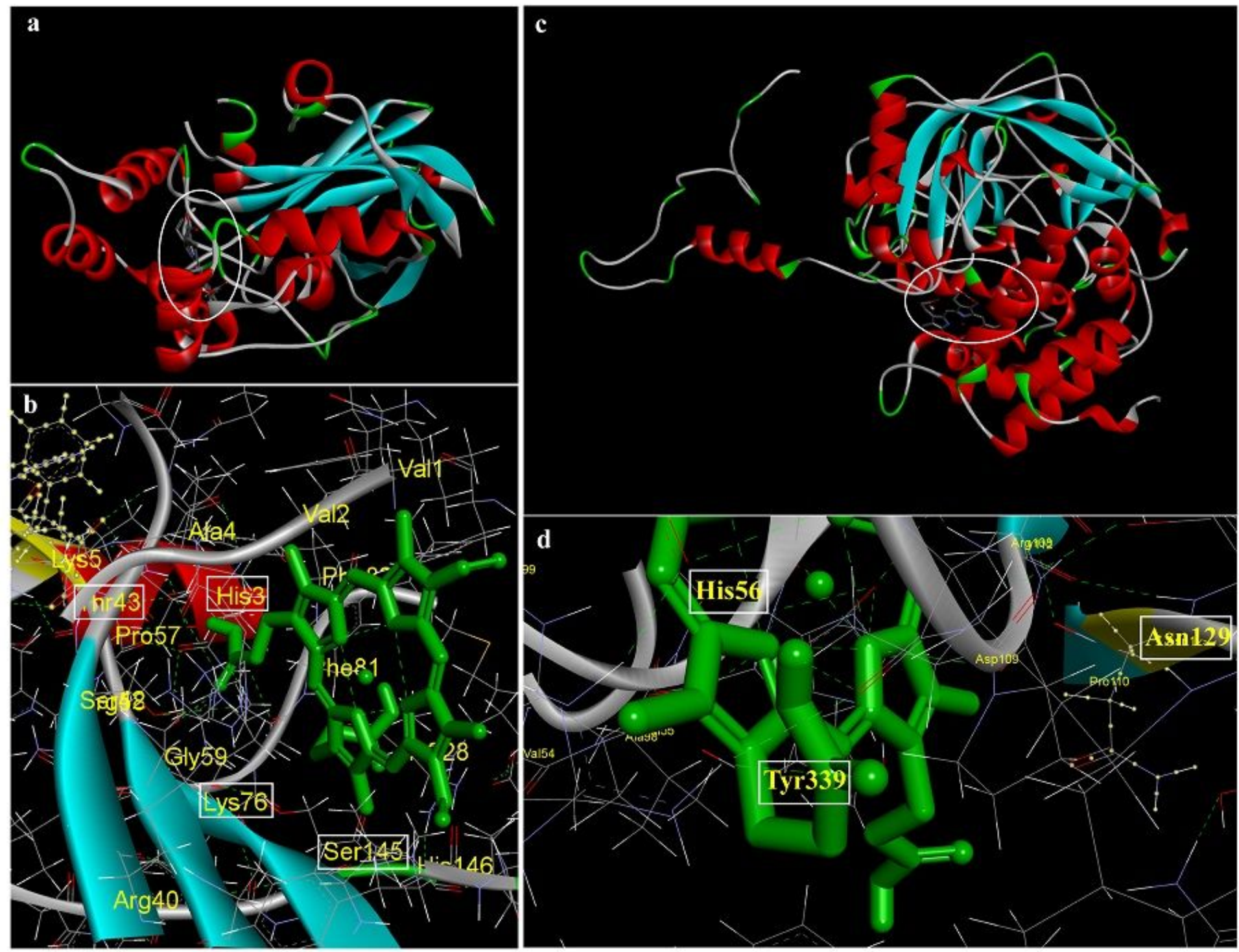

Figure 9 
$(a, c)$ Predicted 3D structure of CAT protein in Euplotes aediculatus (a) and Euplotes vannus (c) where the white circle represents the active site; $(b, d) 3 D$ representation of active site of CAT protein in $E$.

aediculatus (b) and E. vannus (d) showing the crucial residues (marked in white boxes) involved in the catalytic reaction 